\title{
Blended learning: pedagogy, learning styles, and assessment activities in the classroom
}

\author{
Mohd Azli Yeop*, Kung-Teck Wong, Pauline Swee Choo Goh \\ Universiti Pendidikan Sultan Idris, Tanjung Malim, Malaysia
}

\section{A R T I C LE IN F O}

\section{Article history:}

Received 17 August 2016

Received in revised form

29 October 2016

Accepted 3 November 2016

\section{Keywords:}

Blended learning

Frog-virtual learning environment

Pedagogy

Learning styles

\begin{abstract}
A B S T R A C T
A change on the education system is essential in order to produce positive impacts to the success of students; hence, preparing them for the 21st century globalization challenges. The advanced technology nowadays which is both dynamic and futuristic ought to catalyses innovation within the education system of Malaysia. As such, the Ministry of Education (MOE) of Malaysia has taken proactive steps and innovate the education system in line with the current technology. Smart school is one of the results of the initiative and to ensure the success of the smart school concept, MOE has implemented a blended learning platform known as the Frog-Virtual Learning Environment (Frog VLE). Nevertheless, the Frog VLE remains new and hardly practiced among educationist; therefore, this study aims to highlight the Frog VLE in details and how it can be practice within the classroom.
\end{abstract}

(C) 2016 The Authors. Published by IASE. This is an open access article under the CC BY-NC-ND license (http://creativecommons.org/licenses/by-nc-nd/4.0/).

\section{Introduction}

Reforms of the education system are essential in producing positive impacts to the success of students and prepare them for the challenges of $21^{\text {st }}$ century and its globalization. Technological development is so dynamic and futuristic and it has been proven it contributions in the education system in Malaysia.

Recognizing this situation, the Ministry of Education (MOE) has taken proactive steps in drafting the new changes in the education system in line with the current development of technology in teaching and learning.

With the new initiatives to ensure the success of the smart school concept, MOE has introduced a virtual platform which is known as -Frog Virtual Learning Environment (VLE Frog). VLE Frog is a Learning Management Platform aims to provide a virtual learning environment and E-Learning for teachers and students use that characterized by flexibility and mobility. Using this platform, all information and soft copy files stored on cloud storage (cloud storage). It can be reached at anytime and anywhere via the internet for the purpose of

\footnotetext{
* Corresponding Author.

Email Address: azliyeop@gmail.com (M. A. Yeop)

https://doi.org/10.21833/ijaas.2016.11.007

2313-626X/C 2016 The Authors. Published by IASE.

This is an open access article under the CC BY-NC-ND license

(http://creativecommons.org/licenses/by-nc-nd/4.0/)
}

learning (1BestariNet Project, Ministry of Education).

Many educators and researchers believe that it is crucial for educators to use technologies as a tool to facilitate students' learning toward educational goals as the importance of technology in society has increased dramatically. Furthermore, the World Wide Web allows teachers to educate students beyond the traditional textbook and to extend the classroom to the world. The World Wide Web also offers opportunities for students and teachers to talk, work and share interesting ideas with people from different locations via this new communication media.

The importance of integrating computer in education had been proven when the Ministry of Education launched the Smart School. The Smart School became one of the seven flagship applications in Malaysia of the Multimedia Super Corridor (MSC) project in the year 1997. The Smart School project would prepare school leavers for the information age and equip them with information technology competencies. This will help them to develop their potential to face the advancement of technology. This project had involved a major transformation of the Malaysian school system. In other words, computer technology is indispensable for the success of the Smart Schools. Multimedia courseware, presentation facilities and e-mail are required in classroom settings, while library and computer laboratories are resources that will facilitate learning and teaching. Some of the expected changes 
include a more widespread use of computers and related information and communications technology in the classroom, and also teachers' knowledge and skills in computer technology.

However, the smart school was reported as status failed to achieve its objective based on the report from Auditor General's Report, Series 3, 2013. This failure may be due no dissemination of pedagogical methods, learning styles, and assessment activities in the implementation process in the classroom. Most interviewed teachers think that they have not clear guidelines and monitoring tools in the implementation of blended learning in teaching and learning. Based on these problems, this paper aims to explore the pedagogical methods, learning styles and assessment activities that believe could improve the performance and integration of blended learning in the classrooms.

\section{Blended learning}

Since the introduction of educational technologies in the mid 1970's, technologies in the classrooms have been thought as the solution to a myriad of social, economic and educational problems. From that moment onwards, research into its use in the educational world began. Blended learning is the learning environment that exists on the integration of technology in the learning process together with traditional pedagogical practices. Blended learning is meant is the face to face learning (teachers and students) and online learning or technology as the main medium of instruction. In order to implement a blended learning in teaching and learning, there are various things that need to be addressed, among them is the pedagogical aspects, learning styles, the activities that are appropriate for them and finally teachers should know how to assess and monitoring the implementation and the success of blended learning. The paper will also discuss how blended learning can be successfully implemented in schools.

\section{The importance of blended learning in teaching and learning}

Since the technology is so rapidly and dynamically use in teaching and learning, SavinBaden et al. (2010) has noted that the technology has been part of the process in teaching and learning. Pedagogical practices in $21^{\text {st }}$ should integrate technology in the process of designing and developing instructional design. Tsai (2014) also explained that students and teachers now urgently require a form of pedagogical practices towards technology-web environments which believe able to engage students in learning and create interesting classrooms. Therefore, it is important to plan and design of learning (pedagogy) which coincides with the specific needs of today's students and their learning styles. In line with blended learning approach, students should be exposed to a significant learning experience and an opportunity to improve their learning achievements, with the active involvement in the learning activities for traditional (face to face) and online learning (ICT-based). Besides, Banyen et al. (2016) recommend appropriate pedagogy for blended learning is learning to face (face to face) and pedagogical practices ICT based learning.

In short, face-to-face learning is learning-based real-time interaction between teacher and student in the classroom to help students transfer of learning. While learning via ICT is using web-based learning (example: e-learning, VLE, LMS, Moodle and MOOC) as the main platform learning process. Bath and Bourke (2010), noted it should focus the use of blended learning technology to improve the quality of the student learning experience through interactive learning activities (online) and supported by a conducive face interaction between students and teachers in the classroom. For example, using of technology to support communication and collaboration, assessment and management for the success of the learning process. Studies have indeed shown that the use of technologies in schools can have a beneficial effect, not only on the students' achievement but also on their motivation to learn their learning atmosphere in the classroom, and the teachers' willingness to experiment with a new and innovative instructional approach.

\section{Models and learning styles in blended learning}

There are many models that reflect students' learning styles. Among the models of learning styles, Felder-Silverman model is one of the most common models in the implementation of blended learning in classrooms concept. In the study of Laine et al. (2015). The study also included the FelderSilverman model in explaining the learning styles appropriate for a blended learning approach. In the Felder-Silverman model, it has divided into four dimensions, namely; active-reflective, sensing, Intuit, visual-verbal and sequential-global. Indeed, the findings from Laine et al. (2015) also proven that learners or students who have active-reflective learning styles have a greater chance to digest a blended learning pedagogical environment. In Felder-Silverman model, active reflective learning styles generally reflect the trend; how students process information. Whereas, active students are more likely to learn while doing something active and they are also very good work in groups. While, the reflective learners prefer to think before they are attempting an action.

The advantages of active learning style-reflective in helping students succeed in learning a blended learning process is believed to be influenced by the fact that students are active (active) benefit from interactive learning and interaction between teachers and students. While students reflective provides and supports learning based on student choice (learning based on the ability of students or self-paced learning) (Laine et al., 2015), The combination of features and characteristics of this 
learning styles is important to be considered while integrate blended learning approach.

Whereas, in the study of Akkoyunlu and Soylu (2008), contended that there was no significant difference in student achievement based on students' learning styles. Analysis on learning styles based on Kolb's model shows those students with style "assimilators" is the most active student learning in blended learning. However, the findings from Çakıroğlu (2014) has different views, where the findings of his study showed a significant relationship between students' learning styles, study habits and performance of integrated technology is online learning. Formulation studies show learning styles "Vergers and Accommodators" is correlated (have a strong relationship) with the score of high, thus reflect an exact match between learning styles and study habits and methods of instructional (Learning blended) can produce the performance of academics who better. Therefore, the design of integrated ICT learning (blended learning) should be well designed to produce effective learning based on learners' learning styles. So, for designing an effectiveness learning (blended learning), an appropriate strategies should be used to address the different learning styles of students. Hence, the different learning styles can be adopted in blended learning pedagogical practices.

\section{Activities blended learning}

Blended learning activities are highly dependent on pedagogy, learning experience, learning resources and models that are used to implement the learning process (Bailey et al., 2015; Bath and Bourke, 2010), The following table is a summary of a blended learning activities that can be implemented based on the pedagogy of learning (Table 1).

Table 1: Activities blended learning

\begin{tabular}{|c|c|c|}
\hline & Face to face learning & Learning with ICT \\
\hline $\begin{array}{l}\text { Learning } \\
\text { resources }\end{array}$ & $\begin{array}{l}\text { Textbook } \\
\text { Workbooks } \\
\text { reading } \\
\text { Note teacher } \\
\text { Table learning } \\
\end{array}$ & $\begin{array}{l}\text { Reading is online } \\
\text { Online learning guide } \\
\text { Website links } \\
\text { Activities of self-paced online learning } \\
\text { Schedule online learning }\end{array}$ \\
\hline Collaborative & $\begin{array}{l}\text { Small group work } \\
\text { Discussion } \\
\text { Main role } \\
\text { debate } \\
\text { project work }\end{array}$ & $\begin{array}{l}\text { Discussions, forums, debates and role- } \\
\text { play on-line (virtual classroom) } \\
\text { Small group work in virtual (meeting } \\
\text { room) } \\
\text { Build and share online learning } \\
\text { resources. }\end{array}$ \\
\hline Learning & $\begin{array}{l}\text { Lecture } \\
\text { tutorial } \\
\text { Workshops / seminars } \\
\text { Practical / internship } \\
\text { working group } \\
\end{array}$ & $\begin{array}{l}\text { Video footage of teaching } \\
\text { Webcast } \\
\text { Virtual classrooms (online) }\end{array}$ \\
\hline Communication & $\begin{array}{l}\text { Talk face to face teacher-student } \\
\text { Notice on the notice board } \\
\text { Announcements role in the } \\
\text { classroom } \\
\text { Official letter }\end{array}$ & $\begin{array}{l}\text { email } \\
\text { Notice is online } \\
\text { space forum } \\
\text { Online chat rooms }\end{array}$ \\
\hline Student activity & $\begin{array}{l}\text { Drill on paper } \\
\text { Self-learning } \\
\text { reading } \\
\text { Reading reflection }\end{array}$ & $\begin{array}{l}\text { Drill through online } \\
\text { Online testing } \\
\text { Reading reflection is online } \\
\text { e-portfolio }\end{array}$ \\
\hline
\end{tabular}

Source: Adaptation of "Getting Started with Blended Learning" by Bath and Bourke (2010).

\section{Assessment of blended learning}

According to Rossett and Frazee (2006), Blended learning should be assessed based on:

1. The process of continuous learning.

2. Transparent and comprehensive.

There are several criteria that can be referred to perform an evaluation of a blended learning process. These are:

1. The student's willingness and ability to achieve learning objectives (complete a course of study).

2. Active participation of students.

3. Reaction of students to learning activities, learning outcomes.
4. Mastery the content knowledge and skills required. According to the studies by Bath and Bourke (2010) and Bailey et al. (2015), they suggested an evaluation of blended learning must be carried out based learning strategy used (Table 2).

\section{Conclusion}

Based on the discussion above, it can be concluded that blended learning is a teaching method that requires pedagogical methods, learning styles, and assessment of its activities. Teachers should understand more thoroughly the appropriate pedagogical methods to implement blended learning. 
In addition, teachers should also be able to identify their students' learning style before implementing blended learning.

Table 2: Assessment of a blended learning

\begin{tabular}{|c|c|c|}
\hline & Face to face learning & Learning with ICT \\
\hline \multirow{3}{*}{ Assessment } & Examinations/Tests & Online testing \\
& project & Ratings of online student assignment \\
& Performance evaluation & Essay/writing \\
Oral exam/quiz & environment \\
& products & Task (groups) or individuals through a virtual learning \\
& & Involvement \\
\hline
\end{tabular}

The activities should be designed to involve the use of technology and teaching aids. This is because blended learning is a pedagogy method that compliance with the models of learning to meet individual learning styles. This process is conducted in an interactive learning environment between virtual learning environment and face to face method in order to achieve learning objectives.

\section{References}

Akkoyunlu B and Soylu MY (2008). A study of student's perceptions in a blended learning environment based on different learning styles. Educational Technology and Society, 11(1): 183193.

Bailey J, Duty L, Ellis S, Martin N, Mohammed S, Owens D and Wolfe J (2015). Blended learning Implementation Guide 3.0. Available online at: http://digitallearningnow.com/site/uploads/201 3/09/BLIG-3.0-FINAL.pdf

Banyen W, Viriyavejakul $\mathrm{C}$ and Ratanaolarn $\mathrm{T}$ (2016). A blended learning model for learning achievement enhancement of Thai undergraduate students. International Journal of Emerging Technologies in Learning, 11(4): 48-55.
Bath D and Bourke J (2010). Getting started with blended learning. Griffith Institute for Higher Education, Queensland, Australia.

Çakıroğlu Ü (2014). Analyzing the effect of learning styles and study habits of distance learners on learning performances: A case of an introductory programming course. The International Review of Research in Open and Distributed Learning, 15(4): 161-184.

Laine S, Myllymäki M and Hakala I (2015). The role of the learning styles in blended learning. In the $7^{\text {th }}$ International Conference on Education and New Learning Technologies, Barcelona, Spain.

Rossett A and Frazee RV (2006). Blended learning opportunities. American Management Association, New York, USA.

Savin-Baden M, Gourlay L, Tombs C, Steils N, Tombs G and Mawer M (2010). Situating pedagogies, positions and practices in immersive virtual worlds. Educational Research, 52(2): 123-133.

Tsai CW (2014). A quasi-experimental study of a blended course integrated with refined webmediated pedagogy of collaborative learning and self-regulated learning. Interactive Learning Environments, 22(6): 737-751. 